\title{
HUBUNGAN BEBAN KERJA DAN MASA KERJA DENGAN KELUHAN NYERI LEHER PADA PENJAHIT DI LEMBAGA LATIHAN KERJA LUBUK PAKAM TAHUN 2020
}

\author{
Delita $\mathrm{Br}$ Panjaitan ${ }^{1}$, Raisha Octavariny ${ }^{2}$, Sri Melda Br Bangun ${ }^{3}$, Anggi \\ Isnani Parinduri ${ }^{4}$, Ade Julfiani Ritonga ${ }^{5}$ \\ Progaran Studi Kesehatan Masyarakat Fakultas Kesehatan Masyarakat \\ Institut Kesehatan Medistra Lubuk Pakam \\ Jl. Sudirman No.38 Lubuk Pakam Kec. Lubuk Pakam Kab. Deli Serdang, \\ Sumatera Utara \\ Email: delita.lita16@gmail.com \\ DOI $10.35451 / \mathrm{jkg} . v 3 \mathrm{i} 2.599$
}

\begin{abstract}
Complaints of neck pain are a complaint on the part of the skeletal muscle as a result of forced movement and receiving heavy loads for a long time. Tailoring is one of the jobs that has a high risk of experiencing neck pain complaints. The rotation of the spine when the body is bending is a factor in neck pain complaints that are often complained of by tailors. This work activity will indirectly endanger health. This study aims to determine the relationship between workload and work period with complaints of neck pain in tailors at the Lubuk Pakam Training Institute in 2020. The type of research used is quantitative with a cross sectional design. The population of this study were 30 workers at the Lubuk Pakam training institute using the total sampling technique. Data collection by questionnaire. Data analysis used the chi-square test at the level of confidence level of 95\% and $a=0.05$. The results showed that there was a significant relationship between workload $(p=0.024)$ and length of service $(p-0.016)$ with complaints of neck pain in tailors at the Lubuk Pakam Training Institute. It is advisable for tailors to pay more attention to health and safety while working without forcing the body to work and regulating good working hours, adequate rest, stretching while working and paying attention to the dangers that can occur in the work environment.
\end{abstract}

\section{Keywords: Workload, work mass, neck pain complaints}

\section{Pendahuluan}

Kesehatan kerja merupakan salah satu bidang kesehatan masyarakat yang memfokuskan perhatian pada pekerja (Depkes RI, 2016). Kesehatan kerja bertujuan agar pekerja memperoleh derajat kesehatan setinggi-tingginya baik fisik, mental maupun sosial (Sumamur, 2018).

Penggunaan kerja otot yang tidak terkontrol, aktivitas terus menerus, posisi tubuh yang statis dalam waktu lama dapat menimbulkan keluhan nyeri leher (Soedirman, 2016). Massa kerja dan beban kerja adalah dua faktor penyebab keluhan nyeri leher (Tarwaka, 2018).

Setiap pekerjaan memiliki beban kerja berbeda. Penjahit adalah salah satu pekerjaan yang berisiko mengalami keluhan nyeri leher akibat penekanan pada bahu (Nurmianto, 2018).

Pada saat bekerja penjahit banyak melakukan aktivitas dalam posisi duduk dalam jangka waktu yang lama (Saleh, 2019). 
World Health Organization (WHO) menyatakan bahwa salah satu penyebab kematian dan kesakitan di seluruh dunia disebabkan resiko pekerjaan. Dalam Global Estimates of Occupational Accidents and Work tahun 2017, jumlah pekerja meninggal akibat penyakit kerja sebanyak 2.4 juta. Di Indonesia, menurut Riskesdas tahun 2019, angka prevalensi kesakitan akibat nyeri leher terdiagnosis sebesar $24.7 \%$. Prevalensi keluhan nyeri leher terdiagnosis di Sumatera Utara sebesar $19,1 \%$.

Penelitian Dariana (2017), pada 251 pekerja bagian jahit sepatu yang melakukan pekerjaannya dengan posisi duduk dalam waktu lama dan berulang ulang didapatkan keluhan nyeri leher sebesar 53,8\%. Dari hasil penelitian tersebut diperoleh ada hubungan beban kerja dengan massa kerja. Berputarnya tulang belakang saat tubuh membungkuk merupakan faktor penyebeb nyeri leher. Secara tidak langsung, aktivitas kerja tersebut akan membahayakan kesehatan (Sari, 2018).

Lembaga Latihan Kerja Lubuk Pakam adalah salah satu tempat pelatihan penjahit di bidang industri informal. Hasil wawancara pada penjahit di lembaga latihan kerja bahwadari 10 responden terdapat 7 responden yang mengalami keluhan nyeri leher, sakit dan tegang, tetapi ada juga pekerja yang tidak mengalami keluhan tersebut.

\section{METODE PENELITIAN}

Jenis penelitian yang digunakan pada penelitian ini yaitu penelitian kuantitatif dengan rancangan cross sectional. Populasi dalam penelitian ini adalah seluruh pekerja di lembaga latihan kerja lubuk pakam sejumlah 30 orang. Pengambilan sampel dengan menggunakan tehnik Total sampling yaitu seluruh populasi dijadikan sampel.

Pengumpulan data dengan kuesioner yang terdiri dari 3 kuesioner yaitu beban kerja, masa kerja dan keluhan nyeri leher. Setelah data terkumpul, data diolah dengan uji chi square (alpha $=5 \%)$.

\section{HASIL}

Tabel 1. Distribusi Frekuensi Beban Kerja pada Penjahit di Lembaga Latihan Kerja Lubuk Pakam

\begin{tabular}{ccc}
\hline Beban & \multicolumn{2}{c}{ Frekuensi } \\
\cline { 2 - 3 } kerja & $\mathbf{n}$ & $\mathbf{\%}$ \\
\hline Sedang & 13 & 43,3 \\
Berat & 17 & 56,7 \\
\hline TOTAL & $\mathbf{3 0}$ & $\mathbf{1 0 0 , 0}$ \\
\hline
\end{tabular}

Tabel 1 diperoleh mayoritas beban kerja penjahit adalah berat $(56,7 \%)$, dan beban kerja sedang $(43,3 \%)$.

Tabel 2. Distribusi Frekuensi Massa Kerja pada Penjahit di Lembaga Latihan Kerja Lubuk Pakam

\begin{tabular}{ccc}
\hline \multirow{2}{*}{ Masa kerja } & \multicolumn{2}{c}{ Frekuensi } \\
\cline { 2 - 3 } & $\mathbf{n}$ & $\mathbf{\%}$ \\
\hline$<6$ tahun & 23 & 76,7 \\
$\geq 6$ tahun & 7 & 23,3 \\
\hline TOTAL & $\mathbf{3 0}$ & $\mathbf{1 0 0 , 0}$ \\
\hline
\end{tabular}

Tabel 2 diperoleh mayoritas masa kerja penjahit adalah $<6$ tahun $(76,7 \%)$, dan masa kerja $\geq 6$ tahun $(23,3 \%)$.

Tabel 3. Distribusi Responden Berdasarakan Keluhan Nyeri Leher pada Penjahit di Lembaga Latihan Kerja Lubuk Pakam

\begin{tabular}{crr} 
Keluhan & \multicolumn{2}{c}{ Frekuensi } \\
\cline { 2 - 3 } nyeri leher & n & $\%$
\end{tabular}


Jurnal Kesehatan Masyarakat \& Gizi, e-ISSN: 2655-0849

Vol. 3 No.2 Edisi November 2020 - April 2021

https://ejournal.medistra.ac.id/index.php/JKG

Received: 24 Maret 2021 :: Accepted: 17 April 2021 :: Published: 30 April 2021

\begin{tabular}{ccc}
\hline $\begin{array}{c}\text { Tidak ada } \\
\text { keluhan } \\
\text { Ada keluhan }\end{array}$ & 6 & 20,0 \\
\hline TOTAL & $\mathbf{3 0}$ & $\mathbf{1 0 0 , 0}$ \\
\hline
\end{tabular}

Dari tabel 3 diperoleh mayoritas penjahit mengalami keluhan nyeri leher $(80 \%)$, dan penjahit yang tidak mengalami nyeri leher hanya (20\%).

Tabel 4. Hubungan Beban Kerja dengan Keluhan Nyeri Leher pada Penjahit di Lembaga Latihan Kerja Lubuk Pakam

\begin{tabular}{|c|c|c|c|c|c|c|}
\hline \multirow{3}{*}{$\begin{array}{c}\text { Beban } \\
\text { kerja }\end{array}$} & \multicolumn{4}{|c|}{ Keluhan nyeri leher } & \multirow{2}{*}{\multicolumn{2}{|c|}{ Total }} \\
\hline & \multicolumn{2}{|c|}{$\begin{array}{c}\text { Tidak } \\
\text { ada } \\
\text { keluhan }\end{array}$} & \multicolumn{2}{|c|}{$\begin{array}{c}\text { Ada } \\
\text { keluhan }\end{array}$} & & \\
\hline & $\mathbf{n}$ & $\%$ & $\mathbf{n}$ & $\%$ & $\mathbf{n}$ & $\%$ \\
\hline Sedang & 0 & 0,0 & 13 & 100,0 & 13 & 100,0 \\
\hline Berat & 6 & 35,3 & 11 & 64,7 & 17 & 100,0 \\
\hline Total & 6 & 20,0 & 24 & 80,0 & 30 & 100,0 \\
\hline
\end{tabular}

\section{p}

0,024

Tabel 4 diperoleh hasil chi square yaitu ada hubungan beban kerja dengan keluhan nyeri leher pada penjahit di Lembaga Latihan Kerja Lubuk Pakam $(p=0,024 ; p<0,05)$.

Tabel 5. Hubungan Massa Kerja dengan Keluhan Nyeri Leher pada Penjahit di Lembaga Latihan Kerja Lubuk Pakam

\begin{tabular}{|c|c|c|c|c|c|c|}
\hline \multirow{3}{*}{$\begin{array}{l}\text { Masa } \\
\text { kerja }\end{array}$} & \multicolumn{4}{|c|}{ Keluhan nyeri leher } & \multirow{2}{*}{\multicolumn{2}{|c|}{ Total }} \\
\hline & \multicolumn{2}{|c|}{$\begin{array}{l}\text { Tidak } \\
\text { ada } \\
\text { keluhan }\end{array}$} & \multicolumn{2}{|c|}{$\begin{array}{c}\text { Ada } \\
\text { keluhan }\end{array}$} & & \\
\hline & $\mathbf{n}$ & $\%$ & $\mathrm{n}$ & $\%$ & $n$ & $\%$ \\
\hline $\begin{array}{l}<6 \\
\text { tahun }\end{array}$ & 2 & 8,7 & 21 & 91,3 & 23 & 100,0 \\
\hline $\begin{array}{l}\geq 6 \\
\text { tahun }\end{array}$ & 4 & 57,1 & 3 & 42,9 & 7 & 100,0 \\
\hline Total & 6 & 20,0 & 24 & 80,0 & 30 & 100,0 \\
\hline
\end{tabular}

0,016

Tabel 5 diperoleh hasil chi square yaitu ada hubungan massa kerja dengan keluhan nyeri leher pada penjahit di Lembaga Latihan Kerja Lubuk Pakam $(p=0,016 ; p<0,05)$.

\section{PEMBAHASAN}

Berdasarkan hasil analisis penelitian menunjukkan bahwa gambaran beban kerja penjahit di Lembaga Latihan Kerja Lubuk Pakam didapatkan mayoritas beban kerja penjahit adalah berat $(56,7 \%)$, sedangkan beban kerja penjahit yang sedang $(43,3 \%)$ (Tabel 1 ). Beban kerja dari setiap pekerja tidak boleh memiliki beban kerja yang berlebihan. Selain dapat menyebabkan penurunan produktivitas, beban kerja yang berlebihan tersebut dapat menyebabkan terjadinya cidera ataupun keluhan nyeri (Zulfiqar, 2017).

Tabel 2 menunjukkan bahwa mayoritas masa kerja penjahit adalah $<6$ tahun $(76,7 \%)$ dan masa kerja $\geq 6$ tahun $(23,3 \%)$. Kemampuan kerja sangat tergantung usia pekerja. Saat masa kerja meningkat, umur pekerja akan bertambah. Begitupun sebaliknya. Semakin bertambah umur dan masa kerja, maka kekuatan dan ketahanan otot pekerja mulai menurun (Tarwaka, 2015).

Tabel 3 menunjukkan bahwa mayoritas penjahit mengalami keluhan nyeri leher $(80 \%)$, dan penjahit yang tidak mengalaminya (20\%). Umumnya, rasa nyeri dan tidak nyaman pada leher 
yang dirasakan penjahit terjadi setelah mereka selesai bekerja. Ketegangan otot dapat menyebabkan terjadinya gangguan sirkulasi darah dan berisiko nyeri leher (Wiyatno, 2011).

Berdasarkan hasil uji statistic Chi Square menunjukkan bahwa p.value $(0,024)$ berarti ada hubungan beban kerja dengan keluhan nyeri leher pada penjahit di Lembaga Latihan Kerja Lubuk Pakam (tabel 4). Menurut Tarwaka dalam Saleh (2018), saat otot menerima beban kerja berlebihan secara berulang dalam waktu lama akan timbul keluhan muskoskleletal yang diakibatkan oleh kerusakan sendi, ligamen dan tendon.

Menuruti teori Tarwaka tersebut dapat dinyatakan bahwa salah satu penyebab munculnya keluhan nyeri pada leher adalah beban kerja. Penelitian sebelumnya yang terkait dengan hasil penelitian ini antara lain Bolghanabadi, dkk. (2017), Kattang dkk (2018), dan Wiyatno (2011).

Berdasarkan hasil uji statistik Chi Square menunjukkan bahwa $\mathrm{p}$ value $(0,016)$ berarti ada hubungan massa kerja dengan keluhan nyeri leher pada penjahit di Lembaga Latihan Kerja Lubuk Pakam (tabel 5). Semakin lama masa kerja penjahit, semakin lama mereka duduk, maka semakin berisiko mengalami keluhan nyeri pada leher.

Penelitian sebelumnya yang terkait dengan hasil penelitian ini yaitu Dinar dkk (2017) bahwa masa kerja selama lebih dari 5 tahun berhubungan dengan timbulnya keluhan nyeri leher pada pekerja. Namun, hasil penelitian ini tidak sejalan dengan penelitian Andreani dkk (2013) bahwa tidak ada hubungan keluhan subjektif dengan masa kerja.

\section{KESIMPULAN} yaitu:

Kesimpulan pada penelitian ini

1. Mayoritas beban kerja penjahit di Lembaga Latihan Kerja Lubuk Pakam adalah berat $(56,7 \%)$.

2. Mayoritas masa kerja penjahit di Lembaga Latihan Kerja Lubuk Pakam adalah $<6$ tahun $(76,7 \%)$.

3. Mayoritas keluhan nyeri leher penjahit di Lembaga Latihan Kerja Lubuk Pakam adalah sebesar (80\%).

4. Ada hubungan yang signifikan beban kerja dengan keluhan nyeri leher pada penjahit di Lembaga Latihan Kerja Lubuk Pakam dengan nilai $p=0,024$ $(p<0,05)$.

5. Ada hubungan yang signifikan massa kerja dengan keluhan nyeri leher pada penjahit di Lembaga Latihan Kerja Lubuk Pakam dengan nilai $p=0,016$ $(p<0,05)$.

\section{DAFTAR PUSTAKA}

Nurmianto.(2018).Standar Kesehatan dan Keselamatan Kerja di RS Jakarta: Kepmenkes RI

Saleh M.L.(2018).Man Behind The Scene Aviation Safety. Yogyakarta: Deepublish

Sari. (2018).Keluhan Low Back Pain pada Perawat Inap RSUD Selasi Pangkalan Kerinci : Riau

Soedirman. (2016).Hubungan Beban Kerja Perawat Ruang Operasi dengan Kejadian Low Back Pain pada Perawat Ruang Operasi Di RSUD Yogyakarta. Tesis. Yogyakarta: Politeknik 
Kesehatan. Kementerian

Kesehatan.

Sumamur. (2018).Teknik Keselamatan dan Kesehatan Kerja di Industry. Yogyakarta : Graha IImu

Tarwaka. (2018).Standardised Nordic questionnaires for the Analysis of Museculoskeletal Symtoms. Findland : Institute Occupational Health, Departement of Physiology. Kuesioner Low Back Pain.

Tarwaka.(2015).Ergonomi Industri Dasardasar Pengetahuan Ergonomi dan Aplikasi di Tempat Kerja. Surakarta: Harapan Press.

Wiyatno,T.H.(2011).Hubungan antara Beban Kerja dan Sikap Kerja dengan Keluhan Muskuloskeletal pada Buruh Panggul di Kawasan Industri Candi Kota Semarang. Skripsi Diterbitkan Semarang. Fakultas IImu Keolahragaan.

Zulfiqar, M.A.R.(2017).Hubungan antara Beban Kerja Fisik dan Beban Kerja Mental Berbasis Ergonomi Terhadap Tingkat Kejenuhan Kerja Pada Karyawan PT. Jasa Marga (Persero) Tbk Cabang Surabaya Gempol. Jurnal Sains Psikologi, Vol 6, No. 1. 